\title{
Analysis of Implementation of SKKNI Sub Funding and Services for Graduate of Vocation in Banking Sector
}

\author{
Aidha Trisanty \\ D3 Banking and Finance, Universitas Islam Indonesia \\ *Correspondence email: aidha.trisanty@uii.ac.id
}

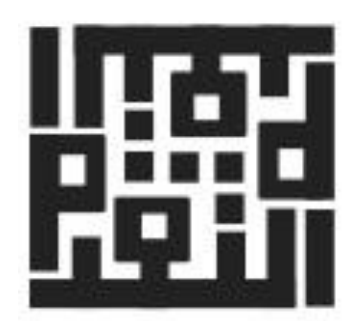

ISSN: $1979-4703(\mathrm{p})$

ISSN: $2527-9726(\mathrm{e})$

\section{Article history:}

Received 14 April 2021

Accepted 15 June 2021

Published 30 June 2021

\section{Keywords:}

SKKNI, KKNI, vocation, banking, competency, funding and services

\begin{abstract}
A B S T RACT
The Indonesian National Work Competency Standards (SKKNI) is one of the efforts to produce graduates ready for work according to industry needs. This includes the SKKNI for the sub-field of Funding and Services, covering four levels of qualifications for a prospective banker that include Teller, Customer Service, Funding Sales Representative, and Funding Product Development Manager. This study aims to determine the implementation of the SKKNI for Sub Financing and Services for Diploma III graduates at the current SMK level. This research is a qualitative descriptive study using observation and interview methods for data collection. The population in this study were all commercial banks and Islamic banks in Yogyakarta. From the questionnaires distributed to users, fourteen banks were consisting of 9 (nine) conventional banks and 5 (five) Islamic banks filled out the questionnaire. It is revealed that there are problems in the implementation of SKKNI since the qualification for the level of position arranged in SKKNI cannot be applied fully because of the gap between the provisions in SKKNI and the rules that apply to the current banking which become the obstacles for vocational schools in preparing the graduates meeting the industry demand.
\end{abstract}

be affected the fastest are generally

\section{Introduction}

In recent years, the need for labor in the banking sector has shown a downward trend in line with the development of digital banking in the banking sector. The number of employees in 2019 was recorded at 232,164 people, down 2.25 percent on an annual basis from 237,497 in 2018 (Richard, 2020). The jobs that will affected front-office positions which will eventually replace by technology (Rahma, 2021). Data from the Financial Services Authority also shows that the number of bank branch offices has decreased in the last five years, as shown in Table 1 below. 
Figure 1.

Number of Bank Offices in Indonesia

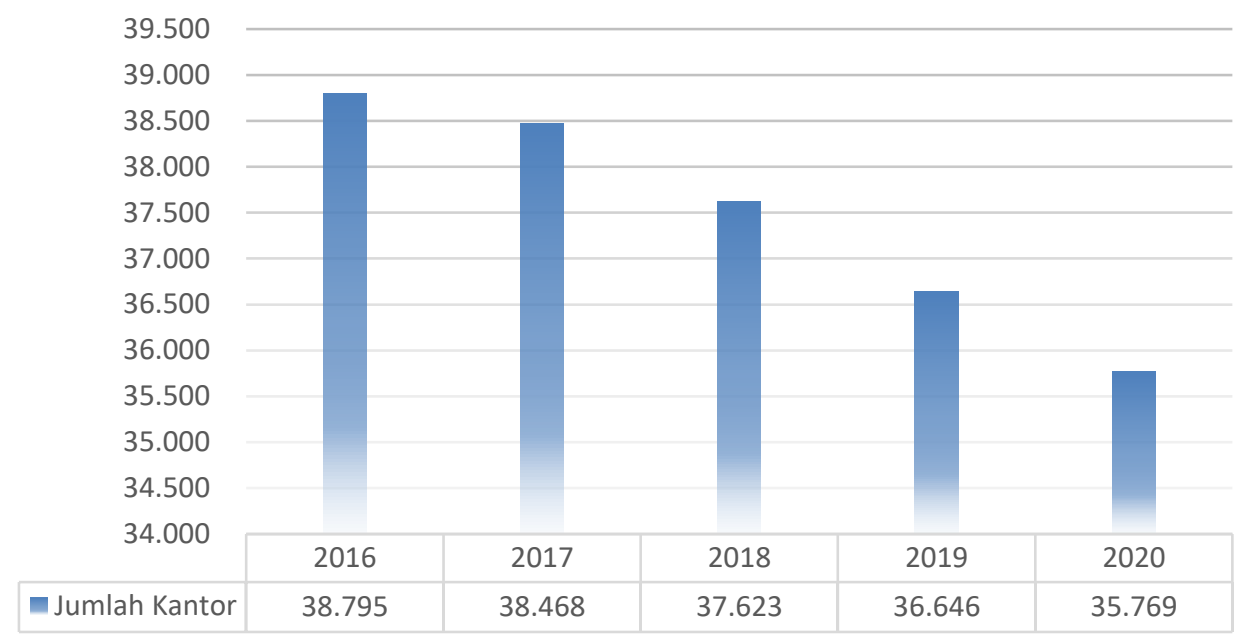

Source : (Otoritas Jasa Keuangan, 2021)

The reduced need for labor in the banking sector is a challenge for higher education institutions, especially those generating graduates for a career in the industrial field. On the other hand, the ASEAN Economic Community (MEA) implementation by the end of 2015 makes the exchange of expert and skilled workers more widely open, as there is an increasing competition in entering the workforce (Triyonggo et al., 2015). Consequently, the business competition in the banking sector is no longer local, but it becomes global. On this account, employees in the banking world, or bankers, must have specific competence and quality to win a position in the banking sector. This indeed becomes a challenge for universities, especially vocational education institutions, which must produce skillful alumni ready for work and qualified to win the tight competition in the work_field (Fariyani et al., 2020; Mubarok, 2018).

To form skillful graduates and competent candidates, the government applies the Indonesian National Work Competency Standards (SKKNI) to education and industry (Gintings, 2019). SKKNI is a formulation of workability covering aspects of knowledge, skills, and expertise. It works attitude relevant to the implementation of duties and terms of office specified following the provisions of legislation (Menteri Tenaga Kerja dan Transmigrasi Republik Indonesia, 2012). One of the SKKNI implementation objectives is to reduce the competence gap between college graduates and the needs of the industrial sector in Indonesia (Kementrian Perindustrian Republik Indonesia, n.d.).

There are currently 22 SKKNI in finance and banking in the banking industry that have been applied to the industry (Badan 
Nasional Sertifikasi Profesi, 2020). Based on the Decree of the Minister of Manpower and Transmigration of the Republic of Indonesia Number 326 of 2013, SKKNI for the category of financial services, Basic Principle Insurance of Non-Insurance Financial Services and Pension Funds, Conventional Banking and Sharia Banking, Financing and Services Subgroups (Menteri Tenaga Kerja dan Transmigrasi Republik Indonesia, 2013).

Based on the SKKNI sub-funding and service, there are four job qualifications: Teller, Customer Service, Funding Sales Representative, and Product Development Manager. With the Indonesian National Qualifications Framework (KKNI) consisting of level 3 (operators), for Tellers and CS, level 4 (operators) for Funding Sales Representatives, and level 5 (technicians/analysts) for Product Development Managers (Menteri Tenaga Kerja dan Transmigrasi Republik Indonesia, 2013). These four qualifications are part of the banker's profession, which includes bank services related to financing and services.

KKNI is a framework of Indonesia's human resource qualification that matches, equalizes, and integrates the education sector with the training sector and work experience in a job-adaptive recognition scheme adapted to structures in various job sectors (Tim KKNI, 2015). For example, the KKNI gap in SKKNI Sub Funding and Services shows that Teller and CS qualification competence is controlled by three equivalent graduates of Vocational High School (SMK). Sales Funding competence is controlled by
Diploma II graduates, and Diploma III graduates control product Development Manager competence.

For vocational higher education, the demand to produce graduates ready for work becomes a must fulfill given the fact that the learning process in vocational education is more specific than the academic education that produces more general competence (Sholihah, 2019). Vocational education was initially designed to build unique skills for educational participants (Tim KKNI, 2015). Therefore, the vocational college should provide its graduates with some skills required by the industry to ease them in the workplace. According to the industrial qualifications and technological developments, preparing vocational high school graduates is one of the goals for vocational education (Daryono et al., 2020). For industry, competence can improve the quality of standard management. Companies that do not have qualified/competent employees will be left behind by other companies (Unggul et al., 2020).

Given one of the objectives of SKKNI implementation to avoid the gap between the graduates generated by higher education and the competencies required by the industry, there should be an inline implementation of SKKNI by both parties, both educational and industrial institutions (Maryanti et al., 2020; Wijaya et al., 2021).

Several studies have been carrying out relating to the importance of implementing SKKNI. Lumempow, Dundu, \& Arsjad (2018) stated that the SKKNI helps all parties increase competitiveness in the global world and 
become a filter for foreign workers who will work in Indonesia. In addition, SKKNI can be a reference for companies in selecting and assessing practitioners who will or have been active in the world of work. (Feronika \& Harahap, 2016).

This study aims to analyze the application of SKKNI sub-funding and services in the banking sector. Several similar studies have been conducted in different fields. Purnamasari, Munjin, \& Atikah (2020) researches Implementation of Structural Competency Standards in Public Sector. Zalzulifa, Nasaruddin, \& Ananto (2020) review Indonesian National Work Competency Standards from the professional Standardization National Agency in Creative Media Standard Polytechnics Jakarta.

This research is interesting because there are no other studies that analyze the application of the SKKNI in finance and banking in Indonesia. This research's result will be input for the government, industry, and higher education to realize the link and match graduates needed by the industry.

\section{Literature Review}

SKKNI is a workable formula covering knowledge, skills, expertise, and work attitudes based on statutory regulations. (Menteri Tenaga Kerja dan Transmigrasi Republik Indonesia, 2012). In Indonesia, the concept of SKKNI grew from a skills passport that was first proposed by the Ministry of Education and Culture (Sayuti, 2015).

The preparation of the work competence standard of Sub Funding and Services becomes the reference in formulating the competent candidate education program in Funding and Services. Therefore, the existence of SKKNI becomes one of the added values for high education graduates, primarily vocational graduates. The Funding \& Services group is part of the bankers' profession, including bank services related to funding and services. The Funding \& Services group is defined as collecting funds from the public in the form of savings. In this case, the bank is a place to save money or invest for the community and provide banking services to other banks (customers). In SKKNI Funding and Services, there are four qualified positions at the level of Teller, Customer Service, Funding Sales Representative, and Product Development Manager (Menteri Tenaga Kerja dan Transmigrasi Republik Indonesia, 2013).

A competency is a general description of the underlying knowledge, skills, and attributes people need to deliver worthy job performance (Stevens, 2013). According to SKKNI, competence is defined as; "The ability required to perform or carry out work based on knowledge, skills and work attitude. Thus, it is possible to formulate competence as an observable person's ability which includes the knowledge, skills, and work attitude in completing a job or task following established performance standards. "While the standard of competence is defined as the standard formulation of the ability that must be owned by someone to perform a task or work based on knowledge, skills and work attitude following the required performance. 
Competence is also defined as the underlying characteristic of a person and is related to the effectiveness of individual performance in his work (Mitrani, A., Dalziel, M., \& Fitt, 1992). Meanwhile, according to (Spencer \& Spencer, 1993), competencies are divided into 2 (two) categories of "threshold competencies" or major competencies that must exist, and "differentiating competencies," i.e., things that distinguish whether someone has a high or low performance.

\section{Research Method}

This research is qualitative descriptive research using observation and interview methods for data collection. The populations of this study are all commercial banks and Islamic banks in Yogyakarta. From the distribution of questionnaires to users, fourteen banks consist of 9 (nine) conventional banks and 5 (five) sharia banks, which fill out the questionnaires. The object of this research is SKKNI Sub Funding and Services applied to the finance industry (banking) for both sharia and conventional banks. The purpose of this study is to determine whether the banking industry has implemented the SKKNI for Sub Financing and Services in the employee recruitment process to determine whether there is a gap between the competence of banking vocational graduates and the competence of human resources required by the banking industry. The data used are primary data (through interviews) and secondary data (through literature studies). Data analysis is carried out in stages starting from identifying the basic rules for the qualification level of the SKKNI, conformity assessment, and recommendations for improvement.

\section{Result and Discussion}

The bank has three main tasks in its operational activities: collecting funds, channeling funds and providing services to customers. The implementation of SKKNI Sub Funding and Services is in the realm of fundraising and services. Banks conduct the fundraising through products such as current accounts, saving accounts, and deposits as a fundraiser. While as service providers, banks provide services through a variety of existing products, including transfer, safe deposit box, payroll, payment point, ATM, and other services.

Implementation of SKKNI Sub Funding and Services includes four job qualifications. Each qualification position consists of units of competence derived into Performance Criteria (KUK) to master by a specific person to be said qualified for the position. The four qualifications of the respective positions are Teller, Customer Service, Funding Sales Representative, and Funding Product Development Manager.

The packaging of competence units of the Funding and Services Sub-Group into the Competency Qualification of the Funding and Services Sub-Group nationally refers to the Indonesian National Qualification Framework (KKNI), as regulated in Presidential Regulation No. 8/2012 on the Indonesian National Qualification Framework, Table 1 below. 


\section{At-Taqaddum}

Vol. 13 No. 1 (2021) Pg. 57-72

\section{Table 1.}

Qualification Level of KKNI in SKKNI Funding Services

\begin{tabular}{|c|c|c|}
\hline No & Position & Qualification KKNI \\
\hline 1 & Teller & III/Senior High School \\
\hline 2 & Customer Service & III/ Senior High School \\
\hline 3 & Funding Sales Representative & IV/Diploma 2 \\
\hline 4 & Funding Product Development Manager & V/Diploma 3 \\
\hline \multicolumn{3}{|c|}{ Source : (Peraturan Menteri Tenaga Kerja Dan Transmigrasi Republik Indonesia, 2013) } \\
\hline $\begin{array}{l}\text { Each } \\
\text { and } \\
\text { charac } \\
\text { comp } \\
\text { level, } \\
\text { Ram? } \\
\text { positic }\end{array}$ & $\begin{array}{l}\text { competency unit of the Funding } \\
\text { Services Sub-Group has } \\
\text { teristics that demonstrate the } \\
\text { exity of job performance, difficulty } \\
\text { level of risk, and responsibility } \\
\text { dhani \& Rahayu, 2020). The } \\
\text { of the competency unit of the }\end{array}$ & $\begin{array}{l}\text { Financing and Bank Services Sub-Group } \\
\text { is determined based on the characteristics } \\
\text { of each competency unit with a } \\
\text { description of the IQF level. The } \\
\text { competency unit of each level of position } \\
\text { on SKKNI Funding Services can be seen } \\
\text { in Table } 2 \text { below. }\end{array}$ \\
\hline
\end{tabular}

Table 2.

SKKNI Competency Unit Funding Services

\section{No Position}

\section{Competency Unit}

1 Teller

1. Performing the initial process of the day

2. Conducting transactions with customers

3. Conducting the end of day process

2 Customer

Service
1. Providing information on bank products and services

2. Handling customer complaints

3. Opening an account

4. Maintaining customer accounts

5. Funding Sales Representative
1. Identifying the bank's Third Party Fund customers Representative
2. Marketing of products/services for collection of bank deposits

3. Serving customer transactions

4. Monitoring the development of Third Party Funds
1. Conducting analysis and follow up of DPK monitoring

2. Establishing a strategy for collecting bank deposits 

Development
3. Preparing the bank's DPK work plan

Manager

4. Developing product program

Source: (Menteri Tenaga Kerja dan Transmigrasi Republik Indonesia, 2013)

Tables 1 and 2 above show that a person is competent when they master the required competence unit. For example, a person is said to be competent for a Teller position when they master three units of competence that include execution of the early process in the day, doing a transaction with the customer and conducting the final process of the day. For CS Units, a person is said to be competent when mastering four competencies that include providing information on bank products and services, handling customer complaints, opening accounts, and maintaining customer accounts. In the Funding Sales Representative unit, recognition of competence is given when a person has a competency unit that includes identifying customers of bank deposits, marketing products/services to collect bank deposits, serving customer transactions, and monitoring the development of Third-Party Funds. The position of Funding Product Development Manager is considered competent if he has mastered the unit of competence, can analyze and monitor the follow-up of DPK, determine DPK-raising strategies, prepare DPK work plans, and develop program products.

\section{Implementation of SKKNI Funding and Services in the Banking Industry}

In implementing the learning process, vocational education institutions should refer to the previously set SKKNI to absorb the generated graduates because their skills/competencies meet the industry's requirements. It is important to know whether the banking industry system has implemented SKKNI Funding and Services to avoid gaps between the resulted graduates and the industrial needs. Following the provisions given in SKKNI there are three levels of KKNI, namely Diploma I, Diploma II, and Diploma III.

By referring to the level of KKNI in SKKNI Funding and Services, following the level of KKNI shown in table 1, the vocational education domain for Diploma II and III levels is in the qualification of Funding Sales Representative and Funding Product Development Manager positions. Therefore, the vocational school should build student competence to produce graduates with expertise in sales funding and Product Development Manager.

Based on the interview and the distribution of questionnaires in 14 banks, it is revealed that no bank that implements SKKNI Funding and Services is absolutely in the selection process to recruit its employees. All banks have not implemented the SKKNI wholly. The most prevalent contradiction is in the qualification level of the Teller and Customer Service positions. Both positions should be filled by graduates of level III qualification that comes from Diploma I. However, many banks still require the position's qualification to be filled by graduates from level V (five) or 
equivalent with Diploma III.

This is certainly a dilemma for vocational education institutions. On the one hand, by following the curriculum which refers to SKKNI Funding and Services, they will not be able to generate the graduates with the competence required by the banking industry, which is currently mostly requiring $\mathrm{HR}$ with the competence of Teller Customer Service for diploma level. But, on the other hand, by following
SKKNI and establishing graduates' competence as sales funding, the graduates will have lesser opportunity to enter the "front-liner competency market." In contrast, the frontline positions are most sought after by the banking industry every time. For example, the competency qualifications of graduates in the current banking sector for the current Teller and CS position can be seen in Table 3 .

\section{Table 3.}

Qualification Level for Teller and CS in Banking Industry

\begin{tabular}{|c|c|c|c|}
\hline No & Bank & Teller & Customer Service \\
\hline 1 & Mandiri & SMA & SMA \\
\hline 2 & BRI & Diploma 3 & Diploma 3 \\
\hline 3 & BCA & SMA & SMA \\
\hline 4 & BNI & Diploma 3 & Diploma 3 \\
\hline 5 & BTN & SMA & Diploma 3 \\
\hline 6 & BTPN & Diploma 3 & Diploma 3 \\
\hline 7 & Mega & Diploma 3 & Diploma 3 \\
\hline 8 & Permata & Diploma 3 & Diploma 3 \\
\hline 9 & BPD DIY & Diploma 3 & Diploma 3 \\
\hline 10 & Bank Syariah Mandiri & SMA & SMA \\
\hline 11 & Muamalat & SMA & SMA \\
\hline 12 & BNI Syariah & Diploma 3 & Diploma 3 \\
\hline 13 & BRI Syariah & Diploma 3 & Diploma 3 \\
\hline 14 & BPRS Madina Syariah & Diploma 3 & Diploma 3 \\
\hline 15 & BPRS MCI & Diploma 3 & Diploma 3 \\
\hline
\end{tabular}

Source: Questionnaire, 2019

From the table, it can be seen that no bank Implements SKKNI for the qualification of Teller and CS. Qualifications that should be fulfilled by
Diploma I graduates are provided for graduates of SMA/SMK and Diploma III. 
In the position of Teller, of the 14 banks, 6 (six) banks require the minimum academic standard of a senior high school graduate (SMA/SMK). In comparison, the remaining 9 (nine) banks require a minimum graduation standard of Diploma III level. Whereas in a Customer Service position, from the existing data, 4 (four) banks require minimum SMA/SMK, and 11 (eleven) banks require the minimum Diploma III qualification. No bank requires SKKNI level according to the level of IV qualification equivalent to Diploma I.

Bank Mandiri, Bank BCA, and Bank Syariah Mandiri use the internship program for employees with high school education levels, while Bank Muamalat does not use an apprenticeship. On apprenticeship status, the company will evaluate the employee's performance before he or she is recommended for the next level.

In addition to these three banks, the entire selection process for Teller and CS positions requires a minimum level of education at Diploma III level. This is a huge opportunity for vocational education and banking institutions to generate and produce graduates who have competencies as Teller and CS.

As for the qualification of the position of Funding Sales Representative and Funding Product Development Manager, according to KKNI it should be filled by graduates from vocational school with Diploma 2 graduate level for Funding Sales Representative and Diploma 3 graduate for level of Funding Product Development Manager.

Regarding the minimum educational qualifications for marketing positions, there are difficulties in interpreting the positions, given the different names of positions in each bank for different marketing positions. This contrasts with the position of front liners in which all banks use the same title of Teller and Customer Service. This necessarily needs to be a particular concern in the implementation of KKNI, since the naming difference will lead to different interpretations to link existing SKKNI with positions in the bank.

The researcher looked at the existing competency units, competency elements, and required Performance Criteria (KUK) to overcome this problem. Based on surveys, observations, and interviews conducted with the fifteen banks for the position of Funding Sales Representative, the average minimum education qualification is from Strata 1 . This is shown from the KUK, which contains the job description or authority of the position with strata one qualification or Officer Development Program (ODP).

In Bank Mandiri, a person is said to be qualified for funding marketing when he has accomplished the strata one education background. At Bank BCA, marketing is referred to as Senior Marketing Development Staff, which requires someone to have prior marketing experience to fill this position. In Bank BTN the position of Sales Funding is possible for anyone with the level of Diploma III. Still, for the funding product development manager position, the KUK is addressed for the undergraduate level or S1.

The unimplemented SKKNI for the qualification of funding positions is also a constraint for universities to form 


\section{At-Taqaddum}

Vol. 13 No. 1 (2021) Pg. 57-72

graduates ready for work. This is like what happened to Teller and CS qualifications. The establishment of SKKNI of the Funding and Services Sub-Group is nationally acknowledged. It becomes a reference for the development of human resources in the banking sector, especially concerning the provision of education and training and competency test in the framework of certification of competence of Fundraisers and Service Provider of Bank Institutions.

Ideally, the vocational education institution of the Diploma level must establish the minimum graduate competency required by SKKNI. The minimum competence should be established to enable the graduates to have expertise following the banking industry's needs. However, the existing gap between competency units and KUK in SKKNI Funding and Services and the current demand of the banking industry put the vocational institutions in trouble. The main problem facing vocational education is that it must conform to SKKNI Funding and Services requirements. However, the competence is no longer in line with the current demand of the banking industry. The industry requires the diploma level to fulfill the position of Teller, CS, and marketing with certain KUK, while the KUK contained in SKKNI for the qualification level five is too high. Each competency element of each unit of competence is presented in table 4 below.

\section{Table 4.}

Performance Criteria of Funding Sales Representative and Funding Product Development Manager

\section{Position Competence Unit Competence Element}

$\begin{array}{lll}\begin{array}{l}\text { Funding Sales } \\ \text { Representative }\end{array} & \begin{array}{l}\text { 1. Identifying the } \\ \text { bank's DPK } \\ \text { customers }\end{array} & \begin{array}{l}\text { a. Preparing the identification of customers of } \\ \text { bank deposits }\end{array} \\ & \begin{array}{l}\text { b. Categorizing (prospective) customers of } \\ \text { third-party funds. } \\ \text { c. Developing a marketing plan for third party } \\ \text { fund products }\end{array}\end{array}$
2. Marketing products services to collect bank deposits.
a. Preparing marketing of third party fundraising products / services
b. Conducting marketing and transactions with (prospective) customers
c. Maintaining relationships with (prospective) customers
d. Evaluating and reporting sales proceeds

3. Serving customer transactions a. Preparing customer service for third party fund collection services

b. Providing transaction services to customers 


\section{Position Competence Unit Competence Element}

\begin{tabular}{|c|c|c|c|}
\hline & & $\begin{array}{l}\text { Monitoring the } \\
\text { development of } \\
\text { Third Party Funds }\end{array}$ & $\begin{array}{l}\text { a. Preparing a portfolio monitoring system of } \\
\text { third party funding of banks } \\
\text { b. Monitoring the development of products } \\
\text { and services related to third party funds }\end{array}$ \\
\hline \multirow[t]{4}{*}{$\begin{array}{l}\text { Funding Product } \\
\text { Development } \\
\text { Manager }\end{array}$} & 1. & $\begin{array}{l}\text { Conducting } \\
\text { analysis and } \\
\text { follow up of } \\
\text { Third Party Fund } \\
\text { (DPK) } \\
\text { monitoring }\end{array}$ & $\begin{array}{l}\text { a. Analyzing data obtained from monitoring of } \\
\text { DPK portfolio } \\
\text { b. Following up on the results of monitoring } \\
\text { analysis of the Third Party Fundraising. }\end{array}$ \\
\hline & 2. & $\begin{array}{l}\text { Establishing a } \\
\text { strategy for } \\
\text { collecting bank } \\
\text { deposits. }\end{array}$ & $\begin{array}{l}\text { a. Planning for the establishment of third party } \\
\text { funding policies and strategies } \\
\text { b. Establishing the purpose of Third Party } \\
\text { Fundraising } \\
\text { c. Formulating a strategy to achieve the } \\
\text { purpose of Third Party Fundraising. }\end{array}$ \\
\hline & 3. & $\begin{array}{l}\text { Preparing the } \\
\text { bank's DPK work } \\
\text { plan }\end{array}$ & $\begin{array}{l}\text { a. Preparing the formulation of a third-party } \\
\text { fundraising work plan } \\
\text { b. Formulating a work plan for third party } \\
\text { fundraising } \\
\text { c. Monitoring \& Evaluation of the realization } \\
\text { of the third-party fundraising work plan }\end{array}$ \\
\hline & 4. & $\begin{array}{l}\text { Developing } \\
\text { product program }\end{array}$ & $\begin{array}{l}\text { a. Preparing the arrangement of third-party } \\
\text { fundraising products } \\
\text { b. Developing third-party fundraising } \\
\text { products (new products and activities) } \\
\text { c. Simulation or trial of third party fundraising } \\
\text { products } \\
\text { d. Completing the preparation of third-party } \\
\text { fundraising products }\end{array}$ \\
\hline
\end{tabular}

Source : (Menteri Tenaga Kerja dan Transmigrasi Republik Indonesia, 2013)

For the minimum level of education Development Manager position, the data position of Funding Product are presented in table 5 below. 


\section{Table 5.}

Qualification Level of Funding Product Development Manager Position in Banking

\begin{tabular}{clc}
\hline No & \multicolumn{1}{c}{ Bank } & Funding Product Development Manager \\
\hline 1 & Mandiri & Strata 1/ODP \\
2 & BRI & Strata 1/ODP \\
3 & BCA & Strata 1/ODP \\
4 & BNI & Strata 1/ODP \\
5 & BTN & Strata 1/ODP \\
6 & BTPN & Strata 1/ODP \\
7 & Mega & Strata 1/ODP \\
8 & Permata & Strata 1/ODP \\
9 & BPD DIY & Strata 1/ODP \\
10 & Bank Syariah Mandiri & Strata 1/ODP \\
11 & Muamalat & Strata 1/ODP \\
12 & BNI Syariah & Strata 1/ODP \\
13 & BRI Syariah & Strata 1/ODP \\
14 & BPRS Madina Syariah & Data belum tersedia \\
15 & BPRS MCI & Data belum tersedia \\
\hline
\end{tabular}

Source: Questionnaire, 2019

In table four, there are 24 (twenty-four) units of competence to master by a Diploma graduate in the qualifications of the two positions. Of the twenty-four units of competence, each competency unit is redefined through Performance Criteria. KUK is used as a basis to determine whether a person is competent. College graduates shall master the KUK according to their respective qualifications.

The results of the KUK observations and interviews revealed that the SKKNI gap was at level five KUK. This KUK is mentioned below: 1) The result is derived from the field observation, audit findings, and analysis of the ALCO meeting. It is revealed that the KUK is in the competency unit analyzing data from monitoring of DPK portfolio. It is generally performed by a special section associated with the treasury. Fresh graduate is located at the level of strata one or through the selection of Officer Development Program (ODP). 2) The third-party fundraising work plan draft is discussed with the Board of Directors for input and approval. In this KUK, there is a gap between the existing KUK and the real conditions in the field, where the position of Funding Product Development Manager of the branch office shall not have 
direct access to the Board of Directors. 3) The concept of reward and punishment is applied to each related work unit. The KUK pin indicates that the level of KKNI for 5 (five) qualifications for the diploma is the managerial level, where this position has another unit below it. 4) The types of third-party fundraising products such as savings, deposits, and checking accounts are designed to be attractive and easy to remember by potential customers. KUK is carried out by a special team that is part of the new product planning with a minimum qualification of strata 1. 5) The requirements for placing funds through savings, time deposits, and current accounts are made simple without neglecting the security aspect. In this KUK, what occurs today is that the requirements process is entirely the authority of the headquarters, where the executing team is generally from experienced staff and ODP. 6) Third-party funding packages are consulted with banking risk management units, banking compliance work units for feedback and approval, and 7) Packages of third-party fundraising products are consulted to the Board of Commissioners or the Board of Directors for input, correction, and approval. However, in its implementation, KUK is not free of gaps where the Product Development Manager of the branch office may not have direct access to the Board of Directors.

The gap between the qualifications required by the current industry and that stipulated in SKKNI indicates the different understandings of the user (banking) in implementing the SKKNI. One of them is due to the lack of involvement of educational institutions in the preparation of SKKNI. It is apparent from the existing
SKKNI that the parties involved in SKKNI preparation are all from the banking industry, such as the Banking Competency Standards Committee, the Formulating Team, and the Verification Team (including the Banking Profession Certification Institution) (Jalinusa et al., 2020). No wonder that there is a difference of understanding in interpreting the level of KKNI in the preparation.

\section{Conclusion}

One of the main objectives of SKKNI is to reduce the gap between graduate's competence produced by higher education institutions and graduate's competence needed by the industry. SKKNI Funding and Services is one of the types of SKKNI implemented in the banking sector mainly for four positions: Teller, CS, Funding Sales Representative, and Funding Product Development Manager. The implementation of SKKNI aims to facilitate the industry to easily find the human resources needed because the human resources generated by higher education institutions are in line with industrial demands. Apart from this objective, still, there is a gap in the implementation of SKKNI Funding and Services since the banking industry has not fully implemented the SKKNI in the recruitment process of employees. In most banks, the third level of KKNI qualification that should be for SMU/SMK graduates (i.e., in Teller and CS positions) is still reserved for Diploma III graduates with 5 (five) levels of qualifications. As for the qualification of the position of Funding Sales Representative and Funding Product Development Manager, SKKNI and KKNI are at the level of Diploma graduate level. However, its implementation is 
intended for graduates of strata one who have KKNI qualification of level 7.

\section{Recommendation}

Given the essential existence of SKKNI to build graduate competence, every party involved in the field should implement SKKNI with no exception. Implementation of SKKNI is essential to produce competent human resources. On this ground, it is necessary to evaluate SKKNI Funding and Services that have been published before. In addition, the Regulation of the Minister of Manpower No. 2 of 2016 on the Indonesian National Competency Standardization System stipulates that to maintain the validity and reliability of the SKKNI that has been previously determined, SKKNI can be reviewed within five years. By referring to these provisions, SKKNI Funding and Services issued in 2013 can be reviewed in 2023. For the next process, the educational institutions should be involved in preparing SKKNI so that there will be an integrated process in building up competent human resources by all parties.

\section{References}

Badan Nasional Sertifikasi Profesi. (2020). Daftar Dokumen SKKNI. Bnsp.Go.Id.

Daryono, R. W., Hariyanto, V. L., \& Usman, H. (2020). Factor analysis : Competency framework for measuring student achievements of architectural engineering education in Indonesia. Research and Evaluation in Education, 6(2), 98-108.

Fariyani, Q., Mubarok, F. K., Masfu'ah, S., \& Syukur, F. (2020). Pedagogical
Content Knowledge of Pre-service Physics Teachers. Jurnal Ilmiah Pendidikan Fisika Al-BiRuNi, 9(1), 99107.

https://doi.org/10.24042/jipfalbirun i.v9i1.3409

Feronika, V., \& Harahap, H. (2016). Kesadaran dan Penerapan SKKNI Kehumasan oleh Kepala Humas di Kementerian. Komunikologi, 13(2).

Gintings, A. (2019). Indonesian national work competency certificate (SKKNI): Ending discrimination to persons with disabilities in formal sectors employment. International Journal of Innovation, Creativity and Change, 5(2), 1376-1395.

Jalinusa, N., Syahrilb, Nabawic, R. A., \& Arbid, Y. (2020). How Project-Based Learning and Direct Teaching Models Affect Teamwork and Welding Skills Among Students. International Journal of Marine Engineering Innovation and Research, 11(11), 85-111. https://doi.org/10.12962/j25481479 .v5i3.7192

Kementrian Perindustrian Republik Indonesia. (n.d.). Kompetensi SDM Industri. Kemenperin.Go.Id.

Peraturan Menteri Tenaga Kerja dan Transmigrasi Republik Indonesia, VII Peraturan Menteri tenaga Kerja dan Transmigrasi 1 (2013).

Lumempow, O. E., Dundu, A. K. T., \& Arsjad, T. T. (2018). ... Standar Kompetensi Kerja Nasional Indonesia (SKKNI) Bidang K3 (Studi Kasus: Pembangunan Gedung Laboratorium Fakultas Teknik Unsrat). Jurnal Sipil Statik, 6(12), 
1085-1094.

Maryanti, N., Rohana, R., \& Kristiawan, M. (2020). the Principal'S Strategy in Preparing Students Ready To Face the Industrial Revolution 4.0. International Journal of Educational Review, 2(1), 54-69. https://doi.org/10.33369/ijer.v2i1.1 0628

Menteri Tenaga Kerja dan Transmigrasi Republik Indonesia. (2012). Sistem Standardisasi Kompetensi Kerja Nasional.

Menteri Tenaga Kerja dan Transmigrasi Republik Indonesia. (2013). Penetapan Standar Kompetensi Kerja Nasional Indonesia Kategori Jasa Kenangan Dan Asuransi Golongan Pokok Jasa Kenangan Bukan Asuransi Dan Pensiun Golongan Perbankan Konvensional Dan Perbankan Syariah Sub Kelompok Funding And Services. Skkni.Kemnaker.Go.Id.

Mitrani, A., Dalziel, M., \& Fitt, D. X. (1992). Competency based buman resource management: value-driven strategies for recruitment, development and reward. Kogan Page.

Mubarok, F. K. (2018). Peran sosialisasi dan edukasi dalam menumbuhkan minat investasi di pasar modal syariah. Inovasi, 14(2), 113. https://doi.org/10.29264/jinv.v14i2. 4119

Otoritas Jasa Keuangan. (2021). Statistik Perbankan Indonesia - Desember 2020.

Purnamasari, I., Munjin, R. A., \& Atikah, I. (2020). Implementation of Structural Competency Standards in Public Sector. 4531, 35-42.

Rahma, T. (2021). Jumlab Karyawan Perbankan Terus Merosot.
Bisnis.Tempo.Co.

Ramadhani, M. A., \& Rahayu, E. (2020). Competency improvement through internship: An evaluation of corporate social responsibility program in vocational school. International Journal of Evaluation and Research in Education, 9(3), 625-634. https://doi.org/10.11591/ijere.v9i3. 20571

Richard, M. (2020). Jumlah Pegawai Bank Turun, Beban Tenaga Kerja Justru Naik. Https://Finansial.Bisnis.Com/.

Sayuti, M. (2015). the Indonesian Competency Standards in Technical and Vocational Education and Training: an Evaluation of Policy Implementation in Yogyakarta Province Indonesia Muhammad Sayuti (Issue September). The University of Newcastle.

Sholihah, L. (2019). the Influence of Question Answer Relationship (Qar) Toward Students Reading Comprehension. The 2nd International Conference on English Language Teaching and Learning (2nd ICON-ELTL) 2019, 2, 211-220.

Spencer, L. M. J., \& Spencer, S. M. (1993). Competence at Work: Models for Superior Performance.

Stevens, G. W. (2013). A critical review of the science and practice of competency modeling. Human Resource Dvelopment Review, 12(86), 86107. https://doi.org/http://dx.doi. org/10.1177/1534484312456690

Tim KKNI. (2015). Kerangka Kualifikasi Nasional Indonesia. Direktorat Jendral Pembelajaran Dan Kemabasiswaan Kemenristekdikti, Dokumen 00,1-9. 


\section{At-Taqaddum}

Vol. 13 No. 1 (2021) Pg. 57-72

Triyonggo, Y., Maarif, M. S., Sukmawati, A., \& Baga, L. M. (2015). Analisis Situasional Kompetensi Praktisi Sumber Daya Manusia Indonesia Menghadapi MEA 2015. Jurnal Manajemen Teknologi, 14(1), 100-112. https://doi.org/10.12695/jmt.2015. 14.1.7

Unggul, A. D. I., Stie, B., \& Surakarta, A. U. B. (2020). Sekolah Tinggi Ilmu Ekonomi. Judicious Journal of Management, $1-15$. https://doi.org/https://doi.org/10. 37010/jdc.v1i2 JUDICIOUS

Wijaya, L., Pentiana, D., \& Puspitasari, E. (2021). Competencies and attributes needed by accounting graduates (alumni) in the world of work (perceptions of Politeknik Negeri Lampung accounting alumni and perceptions of the employer). International Conference on Agriculture and Applied Science, February 2019, 76-83. https://doi.org/10.25181/icoaas.v1i 1.2016

Zalzulifa, Z., Nasaruddin, N., \& Ananto, P. (2020). Review of Indonesian National Work Competency Standards From the Professional Standardization National Agency in Creative Media Standard Polytechnics Jakarta. Jurnal Ilmiah Publipreneur, 7(2), 34-43.

https://doi.org/10.46961/jip.v7i2.87 